\title{
Effect of Ambroxol on Secretion, Production and Gene Expres- sion of Mucin from Cultured Airway Epithelial Cells
}

\author{
Hyun Jae Lee ${ }^{1, a}$, Su Yel Lee ${ }^{1, a}$, Kyoungrai Cho², Byeong Kyou Jeon ${ }^{3}$, Jae Woo Lee ${ }^{4}$, Heung Seog Bae ${ }^{1}$ and \\ Choong Jae Lee ${ }^{1, *}$ \\ ${ }^{1}$ Department of Pharmacology, School of Medicine, Chungnam National University, Daejeon 307-721, \\ ${ }^{2}$ Department of Otorhinolaryngology, Sanggye Paik Hospital, College of Medicine, Inje University, Seoul 139-707, \\ ${ }^{3}$ Department of Radiologic Technology, Daegu Health College, Daegu 702-722, \\ ${ }^{4}$ LG Life Science, Seoul 150-721, Korea
}

\begin{abstract}
In this study, we investigated whether ambroxol significantly affects secretion, production and gene expression of mucin from cultured airway epithelial cells. Confluent primary rat tracheal surface epithelial (RTSE) cells were pretreated with adenosine triphosphate (ATP) for $5 \mathrm{~min}$ and then treated for $30 \mathrm{~min}$ with ambroxol to assess the effect on mucin secretion using ELISA. Additionally, confluent $\mathrm{NCl}-\mathrm{H} 292$ cells were pretreated with ambroxol for 30 min and then stimulated with EGF or PMA for $24 \mathrm{~h}$. The MUC5AC mucin gene expression and mucin protein production were measured by RT-PCR and ELISA. The results were as follows: (1) ambroxol did not significantly affect ATP-induced mucin secretion from cultured RTSE cells; (2) ambroxol inhibited the production of MUC5AC mucin protein induced by EGF and PMA in NCl-H292 cells; (3) ambroxol also inhibited the expression of MUC5AC mucin gene induced by EGF and PMA in NCl-H292 cells. This result suggests that ambroxol can inhibit the production and gene expression of MUC5AC mucin, by directly acting on human airway epithelial cells.
\end{abstract}

Key Words: Airway, Mucin, Ambroxol

\section{INTRODUCTION}

Mucus in the human airway is very important for defense against invading pathogenic microorganisms, chemicals and particles. This defensive action of airway mucus is attributed to the physicochemical properties of mucins. Mucins are multimillion dalton glycoproteins present in the airway mucus and are produced by goblet cells in the surface epithelium as well as mucous cells in the submucosal gland. However, hypersecretion of airway mucus is one of the major symptoms associated with severe pulmonary diseases including asthma, chronic bronchitis, cystic fibrosis and bronchiectasis (Voynow and Rubin, 2009). There are two ways to remove excess mucus from the airway; 1) get rid of the mucus by physical means, ie, aspiration after dilution of mucus, and 2) suppression of secretion and/or production of mucus by pharmacological means. However, clinically, the physical method induces irritation of the airway luminal wall and simulates hypersecretion of mucus through a reflex mechanism. Thus, the

www.biomolther.org

Open Access DOI: 10.4062/biomolther.2011.19.1.065

pISSN: 1976-9148 elSSN: 2005-4483

Copyright $\odot 2011$ The Korean Society of Applied Pharmacology pharmacological means to inhibit mucin secretion and/or production has become an important approach to regulate the hypersecretion of airway mucus (Mutschler and Derendorf, 1995). Secretion of airway mucin is generally stimulated by various agents. Whereas glucocorticoids inhibit the hypersecretion of airway mucins (Mutschler and Derendorf, 1995; Lee et al., 2002), they have various limitations in their application to pharmacotherapy of human diseases involving airway mucus hypersecretion. An alternative approach for regulation of airway mucus hypersecretion is to inhibit the excessive mucin secretion and/or production using agents that have already been clinically used for the management of various diseases. According to a number of studies, ambroxol - one of the clinically-used mucolytics and/or expectorants - was reported to demonstrate anti-oxidative and/or anti-inflammatory activity (Stetinova et al., 2004; Beeh et al., 2008). Ambroxol increased the secretion of pulmonary surfactant which is involved in the expectorant action of ambroxol (Miyata et al., 1986). Ambroxol provoked serous and mucous secretion and restored normal production of mucin in patients suffering from chronic bron-

Received Jul 29, 2010 Revised Sep 15, 2010 Accepted Sep 15, 2010

*Corresponding Author

E-mail: LCJ123@cnu.ac.kr

Tel: +82-42-580-8255, Fax: +82-42-585-6627

${ }^{2}$ These two authors equally contributed to this work. 
chopneumopathy (Aliperta et al., 1986). However, to the best of our knowledge, there are no reports concerning the potential effect of ambroxol on mucin production, gene expression or secretion by airway epithelial cells. Therefore, in this study, we investigated the effect of ambroxol on mucin production and gene expression in $\mathrm{NCl}-\mathrm{H} 292$ cells, a human pulmonary mucoepidermoid cell line, and also ambroxol's effect on mucin secretion as stimulated by adenosine triphosphate (ATP), from primary cultured rat tracheal surface epithelial (RTSE) cells.

\section{MATERIALS AND METHODS}

\section{Materials}

All the chemicals and reagents used in this experiment were purchased from Sigma (St. Louis, MO, U.S.A.) unless otherwise specified.

\section{Primary rat tracheal surface epithelial (RTSE) cell culture}

Animals were housed and cared for in accordance with the Guide for the Care and Use of Laboratory Animals as regulated by Chungnam National University. Tracheas were obtained from male Sprague Dawley (SD) rats, 5 weeks of age (Harlan Sprague Dawley, Indiana, U.S.A.). RTSE cells were harvested and cultured on a thick collagen gel substratum as previously reported (Wasano et al., 1988; Ko et al., 1999). Briefly, animals were euthanized in a $\mathrm{CO}_{2}$ chamber and the tracheas were exposed under aseptic conditions. The tracheas were cannulated using a polyethylene tube through which the tracheal lumen was filled with $0.1 \%$ pronase (Type XIV) prepared in $\mathrm{Ca}^{++}, \mathrm{Mg}^{++}$-free Minimum Essential Medium (MEM, GIBCOBRL, U.S.A.) and incubated at $4^{\circ} \mathrm{C}$ for $16 \mathrm{~h}$. The luminal contents were flushed, and cells were washed twice with $\mathrm{Ca}^{++}$, $\mathrm{Mg}^{++}$-free Minimum Essential Medium containing 10\% fetal bovine serum by centrifugation at $200 \times \mathrm{g}$. The washed cell pellets were dissociated in a growth medium containing Medium 199 and Dulbecco's Modified Eagle's medium (DME) (1:1) supplemented with insulin $(5 \mu \mathrm{g} / \mathrm{ml})$, epidermal growth factor $(12.5 \mathrm{ng} / \mathrm{ml})$, hydrocortisone $(0.1 \mu \mathrm{M})$, fetal bovine serum $(5 \%$ $\mathrm{v} / \mathrm{v}$, Hyclone, Logan, UT, U.S.A.), sodium selenite $(0.01 \mu \mathrm{M})$, retinoic acid $(0.1 \mu \mathrm{M})$, Penicillin $\mathrm{G}(100 \mathrm{U} / \mathrm{ml}$, GIBCO-BRL), Streptomycin $(100 \mu \mathrm{g} / \mathrm{ml}, \mathrm{GIBCO}-\mathrm{BRL})$ and Gentamicin (50 $\mu \mathrm{g} / \mathrm{ml}$ ) ("complete" medium). At this stage, most of the cells were in small aggregates and were plated at a density of $10^{4}$ cells $/ \mathrm{cm}^{2}$ into tissue culture dishes containing a thick collagen gel $\left(0.15 \mathrm{ml} / \mathrm{cm}^{2}\right)$ using collagen type I (Regenmed, Seoul, Korea). Cultures were incubated at $37^{\circ} \mathrm{C}$ in a humidified atmosphere containing $95 \%$ air and $5 \% \mathrm{CO}_{2}$ and culture medium was changed on days $1,3,5$ and 7 .

\section{Treatment of RTSE cells with ambroxol and quantitation of mucins by ELISA}

Confluent RTSE cells were prepared according to the aforementioned method. On culture day 6 , spent medium from each culture well was removed and $200 \mu$ of fresh complete medium was added to each well. Following a $24 \mathrm{~h}$ incubation, the spent media (designated as the pretreatment (PT) sample) was collected and the cultures were washed twice with Dulbecco's phosphate-buffered saline (PBS) without $\mathrm{Ca}^{++}$ and $\mathrm{Mg}^{++}$before chasing for $30 \mathrm{~min}$ in PBS containing varying concentrations of ambroxol (the treatment ( $T$ ) sample).
Ambroxol hydrochloride and ATP were dissolved in doubledistilled, deionized water (DDW) and administered in PBS. The final $\mathrm{pH}$ values of these solutions were between 7.0 and 7.4. PBS solution in this range did not affect mucin secretion by RTSE cells. Floating cells and cell debris were removed by centrifugation of samples at $12,000 \times \mathrm{g}$ for $5 \mathrm{~min}$. The samples were stored at $-70^{\circ} \mathrm{C}$ until assayed for their mucin contents. The amount of mucins in each sample was measured by using enzyme-linked immunosorbent assay (ELISA). PT and T samples were diluted with PBS at 1:10 ratio and $100 \mu$ l of each sample was incubated at room temperature in a 96-well plate for $2 \mathrm{~h}$. Wells were washed three times with PBS and blocked with $2 \% \mathrm{BSA}$ for $1 \mathrm{~h}$ at room temperature. Wells were again washed three times with PBS and then incubated with 100 $\mu \mathrm{l}$ of 17Q2 (Covance, U.S.A.), a mouse monoclonal anti-total mucin antibody, which was diluted with PBS containing $0.05 \%$ Tween $20(1: 1,000)$, and dispensed into each well. After $1 \mathrm{~h}$, wells were washed three times with PBS, and $100 \mu$ of horseradish peroxidase-goat anti-mouse IgG conjugate $(1: 3,000)$ was dispensed into each well. After $1 \mathrm{~h}$, wells were washed three times with PBS. Color reaction was developed with 3,3',5,5'-tetramethylbenzidine (TMB) peroxide solution and stopped with $1 \mathrm{~N} \mathrm{H}_{2} \mathrm{SO}_{4}$. Absorbance was read at $450 \mathrm{~nm}$. The effect of ambroxol on mucin secretion was measured as follows: the amount of mucin secreted during the treatment period was divided by the amount of mucin secreted during the pretreatment period and the ratio was expressed as a secretory index. Means of secretory indices from each group were compared and the differences were assessed using statistics.

\section{$\mathrm{NCl}-\mathrm{H} 292$ cell culture}

$\mathrm{NCl}-\mathrm{H} 292$ cells, a human pulmonary mucoepidermoid carcinoma cell line, were purchased from the American Type Culture Collection (ATCC, Manassas, VA, U.S.A.) and cultured in RPMI 1640 supplemented with $10 \%$ fetal bovine serum (FBS) in the presence of penicillin (100 units $/ \mathrm{ml})$, streptomycin (100 $\mu \mathrm{g} / \mathrm{ml})$ and HEPES $(25 \mathrm{mM})$ at $37^{\circ} \mathrm{C}$ in a humidified, $5 \% \mathrm{CO}_{2} /$ $95 \%$ air, water-jacketed incubator. For serum deprivation, confluent cells were washed twice with phosphate-buffered saline (PBS) and re-cultured in RPMI 1,640 containing $0.2 \%$ fetal bovine serum for $24 \mathrm{~h}$.

\section{Treatment of cells with ambroxol}

Following $24 \mathrm{~h}$ of serum deprivation, cells were pretreated with ambroxol $(1,10$ and $100 \mu \mathrm{M})$ for $30 \mathrm{~min}$ and then treated with EGF $(25 \mathrm{ng} / \mathrm{ml})$ or PMA (10 $\mathrm{ng} / \mathrm{ml})$ for $24 \mathrm{~h}$ in serumfree RPMI 1640. After $24 \mathrm{~h}$, cells were lysed with buffer solution containing $20 \mathrm{mM}$ Tris, $0.5 \% \mathrm{NP}-40,250 \mathrm{mM} \mathrm{NaCl}, 3$ mM EDTA, 3 mM EGTA and protease inhibitor cocktail (Roche Diagnostics, IN, U.S.A.) and collected to measure the production of MUC5AC protein (in 24-well culture plate). The total RNA was extracted for measuring the expression of MUC5AC gene (in 6-well culture plate) by using RT-PCR.

\section{MUC5AC mucin analysis using ELISA}

MUC5AC protein was measured by using ELISA. Cell lysates were prepared with PBS at 1:10 dilution, and $100 \mu \mathrm{l}$ of each sample was incubated at $42^{\circ} \mathrm{C}$ in a 96 -well plate, until dry. Plates were washed three times with PBS and blocked with $2 \%$ BSA (fraction $V$ ) for $1 \mathrm{~h}$ at room temperature. Plates were again washed three times with PBS and then incubated with $100 \mu \mathrm{l}$ of $45 \mathrm{M} 1$, a mouse monoclonal MUC5AC antibody 
(NeoMarkers, CA, USA) (1:200), which was diluted with PBS containing $0.05 \%$ Tween 20 and dispensed into each well. After $1 \mathrm{~h}$, the wells were washed three times with PBS, and 100 $\mu \mathrm{l}$ of horseradish peroxidase-goat anti-mouse IgG conjugate $(1: 3,000)$ was dispensed into each well. After $1 \mathrm{~h}$, plates were washed three times with PBS. Color reaction was developed with 3,3',5,5'-tetramethylbenzidine (TMB) peroxide solution and stopped with $1 \mathrm{~N} \mathrm{H}_{2} \mathrm{SO}_{4}$. Absorbance was read at $450 \mathrm{~nm}$.

\section{Total RNA isolation and RT-PCR}

Total RNA was isolated using an Easy-BLUE Extraction Kit (INTRON Biotechnology, Inc. Kyung-gi-do, Korea) and reverse transcribed by using AccuPower RT Premix (BIONEER Corporation, Daejeon, Korea) according to the manufacturer's instructions. $2 \mu \mathrm{g}$ of total RNA was primed with $1 \mu \mathrm{g}$ of oligo (dT) in a final volume of $50 \mu \mathrm{l}$ (RT reaction). $2 \mu \mathrm{l}$ of RT reaction product was PCR amplified in a $25 \mu$ l volume by using Thermorprime Plus DNA Polymerase (ABgene, Rochester, NY, U.S.A.). Primers for MUC5AC were: (forward) 5'-TGA TCA TCC AGC AGG GCT-3' and (reverse) 5'-CCG AGC TCA GAG GAC ATA TGG G-3'. The size of expected fragment amplified by PCR was $458 \mathrm{bp}$. As quantitative controls, primers for Rig/ S15 rRNA, which encodes a small ribosomal subunit protein (a housekeeping gene that was constitutively expressed), were used. Primers for Rig/S15 were: (forward) 5'-TTC CGC AAG TTC ACC TAC C-3' and (reverse) 5'-CGG GCC GGC CAT GCT TTA CG-3'. The size of expected fragment amplified by PCR was $361 \mathrm{bp}$. The PCR mixture was denatured at $94^{\circ} \mathrm{C}$ for $2 \mathrm{~min}$ followed by 40 cycles at $94^{\circ} \mathrm{C}$ for $30 \mathrm{~s}, 60^{\circ} \mathrm{C}$ for $30 \mathrm{~s}$ and $72^{\circ} \mathrm{C}$ for $45 \mathrm{~s}$. Following PCR, $5 \mu \mathrm{l}$ of PCR products were subjected to $1 \%$ agarose gel electrophoresis and visualized with ethidium bromide under a transilluminator.

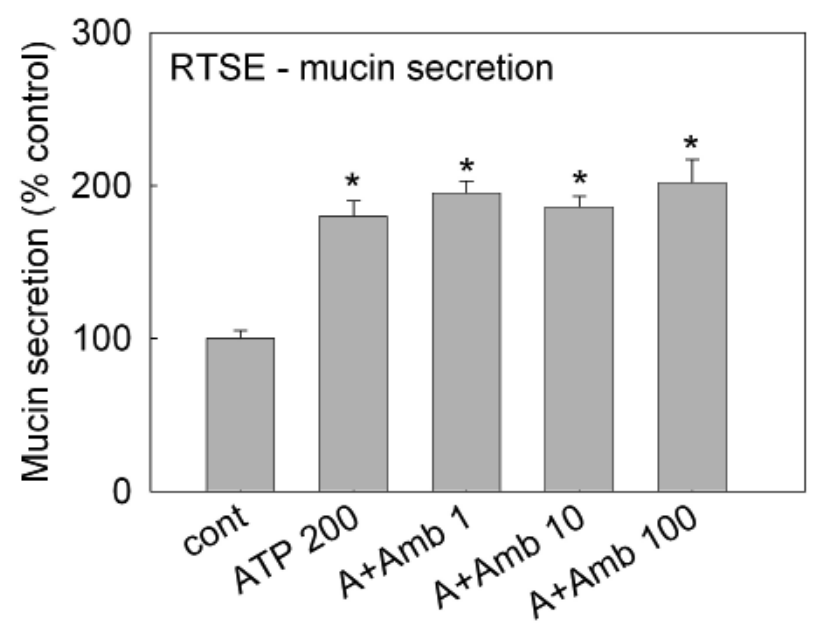

Treatment

Fig. 1. Effect of ambroxol on ATP-induced mucin secretion from cultured RTSE cells. Confluent RTSE cells were chased for 30 $\mathrm{min}$ in the presence of varying concentrations of ambroxol. The amounts of mucin in spent media were measured as described in Materials and Methods. Each bar represents a mean \pm S.E.M. of 4 culture wells in comparison with that of control set at $100 \%$. * Significantly different from control $(p<0.05)$. cont: control, A: ATP 200 , Amb: ambroxol, concentration unit is $\mu \mathrm{M}$.

\section{Statistics}

Means of individual groups were converted to percent control and expressed as mean \pm S.E.M. The difference between groups was assessed using one-way ANOVA and Student's t-test for unpaired samples. $p<0.05$ was considered as significantly different.

\section{RESULTS}

\section{Effect of ambroxol on ATP-induced mucin secretion from cultured RTSE cells}

As shown in Fig. 1, ambroxol did not significantly affect ATP-induced mucin secretion from RTSE cells. The amounts of mucin in the spent media of ambroxol-treated cultures were $100 \pm 5 \%, 180 \pm 10 \%, 195 \pm 8 \%, 186 \pm 7 \%$ and $202 \pm 15 \%$ for control, $2 \times 10^{-4} \mathrm{M}$ of ATP alone, ATP plus ambroxol $10^{-6}$ $\mathrm{M}$, ATP plus ambroxol $10^{-5} \mathrm{M}$ and ATP plus ambroxol $10^{-4} \mathrm{M}$, respectively (Fig. 1).

\section{Effect of ambroxol on EGF-induced MUC5AC production}

As shown in Fig. 2, ambroxol significantly inhibited EGFinduced MUC5AC production from $\mathrm{NCl}-\mathrm{H} 292$ cells at the concentration of $10^{-4} \mathrm{M}$. The amounts of mucin in the cells of ambroxol-treated cultures were $100 \pm 1 \%, 200 \pm 5 \%, 230$ $\pm 7 \%, 243 \pm 14 \%$ and $154 \pm 6 \%$ for control, $25 \mathrm{ng} / \mathrm{ml}$ of EGF alone, EGF plus ambroxol $10^{-6} \mathrm{M}$, EGF plus ambroxol $10^{-5} \mathrm{M}$ and EGF plus ambroxol $10^{-4} \mathrm{M}$, respectively (Fig. 2).

\section{Effect of ambroxol on PMA-induced MUC5AC production}

As shown in Fig. 3, ambroxol significantly inhibited PMAinduced MUC5AC production from $\mathrm{NCl}-\mathrm{H} 292$ cells at the

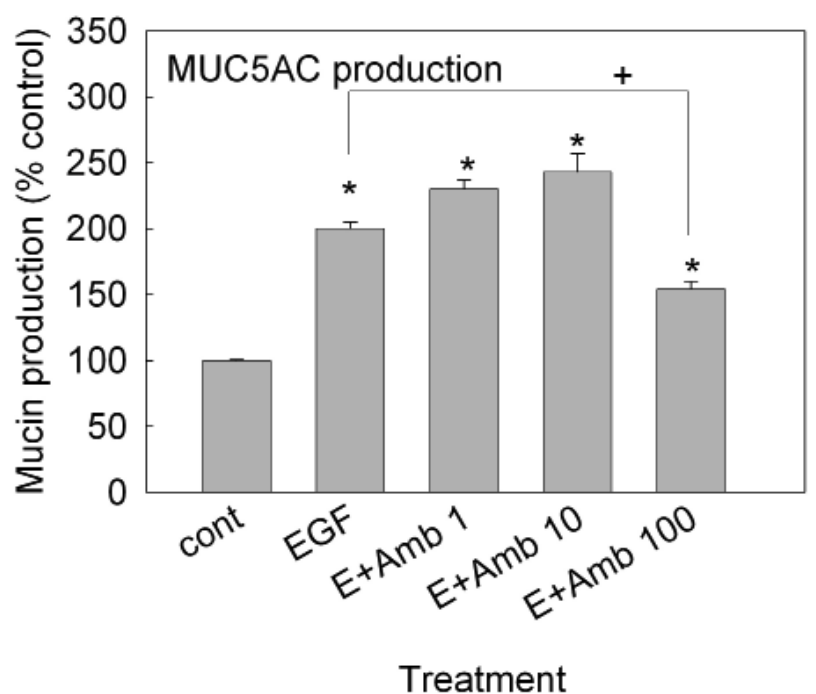

Fig. 2. Effect of ambroxol on EGF-induced MUC5AC mucin production from NCl-H292 cells. NCl-H292 cells were pretreated with varying concentrations of ambroxol for $30 \mathrm{~min}$ and then stimulated with EGF $(25 \mathrm{ng} / \mathrm{ml})$ for $24 \mathrm{~h}$. Cell lysates were collected for measurement of MUC5AC mucin production by ELISA. Each bar represents a mean \pm S.E.M. of 3-4 culture wells in comparison with that of control set at $100 \%$. *Significantly different from control $(p<0.05)$. ${ }^{+}$Significantly different from EGF alone $(p<0.05)$. cont: control, Amb: ambroxol, concentration unit is $\mu \mathrm{M}$. 


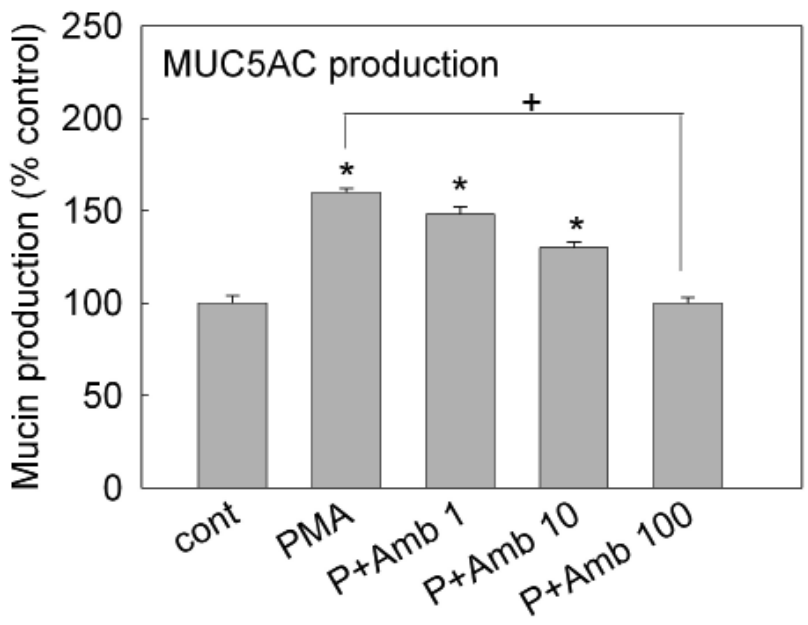

Treatment

Fig. 3. Effect of ambroxol on PMA-induced MUC5AC mucin production from $\mathrm{NCl}-\mathrm{H} 292$ cells. $\mathrm{NCl}-\mathrm{H} 292$ cells were pretreated with varying concentrations of ambroxol for $30 \mathrm{~min}$ and then stimulated with PMA $(10 \mathrm{ng} / \mathrm{ml})$ for $24 \mathrm{~h}$. Cell lysates were collected for measurement of MUC5AC mucin production by ELISA. Each bar represents a mean \pm S.E.M. of 3-4 culture wells in comparison with that of control set at $100 \%$. * Significantly different from control $(p<0.05)$. ${ }^{+}$Significantly different from PMA alone $(p<0.05)$. cont: control, Amb: ambroxol, concentration unit is $\mu \mathrm{M}$.

concentration of $10^{-4} \mathrm{M}$. The amounts of mucin in the cells of ambroxol-treated cultures were $100 \pm 4 \%, 160 \pm 2 \%, 148$ $\pm 4 \%, 130 \pm 3 \%$ and $100 \pm 3 \%$ for control, $10 \mathrm{ng} / \mathrm{ml}$ of PMA alone, PMA plus ambroxol $10^{-6} \mathrm{M}$, PMA plus ambroxol $10^{-5} \mathrm{M}$ and PMA plus ambroxol $10^{-4} \mathrm{M}$, respectively (Fig. 3).

\section{Effects of ambroxol on EGF-induced and PMA-induced MUC5AC gene expression from $\mathrm{NCl}-\mathrm{H} 292$ cells}

As can be seen in Fig. 4, MUC5AC gene expression induced by EGF and PMA from NCl-H292 cells were inhibited by pretreatment with $100 \mu \mathrm{M}$ of ambroxol, respectively (Fig. 4).

\section{DISCUSSION}

Ambroxol, a frequently used mucolytic agent and/or expectorant, was reported to have a wide range of pharmacological anti-inflammatory properties. It demonstrated an inhibitory action on oxidative and nitrosative stress, increased local defense molecules involved in respiratory virus replication, and reduced pro-inflammatory cytokines, chemotaxis of inflammatory cells and tissue lipid peroxidation (Stetinova et al., 2004). Also, ambroxol increased the secretion of pulmonary surfactant and this increase is involved in the expectorant action of ambroxol (Miyata et al., 1986). Ambroxol provoked serous and mucous secretion and restored normal production of mucin in patients suffering from chronic bronchopneumopathy (Aliperta et al., 1986). Development of a potent pharmacological tool for regulating production and/or secretion of mucus could play a significant role in the efficient control of severe respiratory diseases involving hyperproduction and hypersecretion of airway

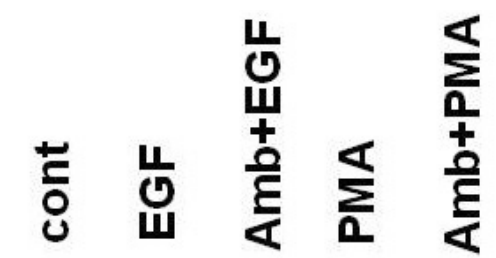

MUC5AC

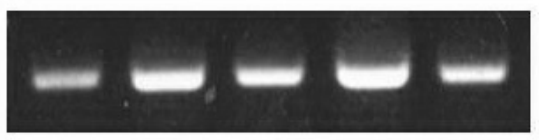

Rig/S15

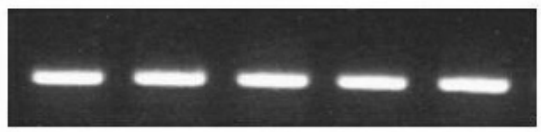

Fig. 4. Effects of ambroxol on EGF-induced and PMA-induced MUC5AC gene expression from $\mathrm{NCl}-\mathrm{H} 292$ cells. $\mathrm{NCl}-\mathrm{H} 292$ cells were pretreated with ambroxol $(100 \mu \mathrm{M})$ for $30 \mathrm{~min}$ and then stimulated with PMA $(10 \mathrm{ng} / \mathrm{ml})$ or EGF $(25 \mathrm{ng} / \mathrm{ml})$ for $24 \mathrm{~h}$. MUC5AC gene expression was measured by RT-PCR. cont: control, Amb: ambroxol.

mucins. Mucins are macromolecular glycoproteins present in the airway mucus and have peptide backbones and carbohydrate branches (Voynow and Rubin, 2009). To date, 20 MUC genes coding peptide backbone of human mucins have been reported and, among them, MUC5AC is highly expressed in airway goblet cells (Rogers and Barnes, 2006; Yuan-Chen Wu et al., 2007). Also, epidermal growth factor (EGF) and phorbol 12-myristate 13-acetate (PMA) were reported to regulate MUC5AC mucin gene expression in the lung (Takeyama et al., 1999; Hewson et al., 2004). MUC5AC mRNA expression was increased after ligand binding to the EGF receptor and activation of the MAPK (mitogen-activated protein kinase) cascade (Takeyama et al., 1999; Takeyama et al., 2000). Phorbol 12-myristate 13-acetate (PMA) is an inflammatory stimulant affecting gene transcription, cell growth and differentiation and induces MUC5AC gene expression in $\mathrm{NCl}-\mathrm{H} 292$ cells (Park et al., 2002; Hewson et al., 2004). Based on these reports, we tried to investigate whether ambroxol affects EGF- or PMAinduced MUC5AC mucin production and gene expression in $\mathrm{NCl}-\mathrm{H} 292$ cells, a human pulmonary mucoepidermoid cell line, which is frequently used for studying intracellular signaling pathways involved in airway mucin production and gene expression (Li et al., 1997; Takeyama et al., 1999; Shao et al., 2003). As shown in results, ambroxol inhibited the production and gene expression of MUC5AC mucin induced by EGF or PMA. This is the first report concerning the action of ambroxol on airway MUC5AC mucin production and gene expression induced by growth factor or phorbol ester. This finding could result in a better understanding of the molecular action mechanism of ambroxol. Although the underlying mechanism of action of ambroxol on MUC5AC mucin production and gene expression is not presently clear, we are trying to examine whether ambroxol acts as a potential regulator of the MAPK cascade after ligand binding to the EGF receptor in mucinproducing $\mathrm{NCl}-\mathrm{H} 292$ cells. Additionally, our group previously examined whether ambroxol affects mucin release from the airway and found ambroxol failed to show any activity on basal mucin release from airway goblet cells (Heo et al., 2005). 
Thus, in the present study, we examined the effect of ambroxol on ATP-induced mucin secretion from cultured RTSE cells, on the basis of the following reports. Nucleotides present in the airway surface liquid controlled mucociliary clearance. This phenomenon was mediated by two purinergic receptor subtypes - P2Y2 receptor and A2 adenosine receptor. Stimulation of P2Y2 receptor by an agonist like ATP was reported to increase airway mucin secretion (Kim et al., 1997; Lazarowski and Boucher, 2009). When airway inflammation occurs, local extracellular ATP concentrations from ruptured cells in the airway can reach high levels, because intracellular ATP concentrations are greater than a few millimolar concentration (Gordon, 1986). However, as shown in "Results", ambroxol did not affect ATP-induced mucin secretion from cultured RTSE cells. This result partially suggests that ambroxol can not affect mucin secretion induced by ATP - a phenomenon reflecting hypersecretion of mucus from airway epithelial cells during inflammation.

In summary, ambroxol inhibited the production and gene expression of MUC5AC mucin without affecting ATP-induced secretion of mucin, from cultured airway epithelial cells. Also, future research should explain why ambroxol can not affect basal and ATP-stimulated mucin secretion (release) despite the fact that it can inhibit production and gene expression of airway mucin.

\section{ACKNOWLEDGMENTS}

This study was partly supported by 2009 grant of the Technology Development Program for Agriculture and Forestry, Ministry for Food, Agriculture, Forestry and Fisheries, Republic of Korea.

\section{REFERENCES}

Aliperta, A., Bellissimo, U., Turco, D. and Antinolfi, G. (1986) Normalization of bronchial exocrine pathology after endobronchial treatment with ambroxol. Int. J. Tissue React. 8, 167-174.

Beeh, K. M., Beier, J., Esperester, A. and Paul, L. D. (2008) Anti-inflammatory properties of ambroxol. Eur. J. Med. Res. 13, 557-562.

Gordon, J. L. (1986) Extracellular ATP: effects, sources and fate. Biochem. J. 233, 309-319.

Heo, H. J., Lee, H. J., Yoon, C. S., Lim, S. P., Seok, J. H., Seo, U. K and Lee, C. J. (2005) Effects of ambroxol, S-carboxymethylcysteine, dextromethorphan and noscapine on mucin release from airway goblet cells. Korean J. Physiol. Pharmacol. 9, 323-326.

Hewson, C. A., Edbrooke, M. R. and Johnston, S. L. (2004) PMA induces the MUC5AC respiratory mucin in human bronchial epithe- lial cells, via PKC, EGF/TGF-alpha, Ras/Raf, MEK, ERK and Sp1dependent mechanisms. J. Mol. Biol. 344, 683-695.

Kim, K. C., McCracken, K., Lee, B. C., Shin, C. Y., Jo, M. J., Lee, C. J. and Ko, K. H. (1997) Airway goblet cell mucin: its structure and regulation of secretion. Eur. Respir. J. 11, 2644-2649.

Ko, K. H., Lee, C. J., Shin, C. Y., Jo, M. J. and Kim, K. C. (1999) Inhibition of mucin release from airway goblet cells by polycationic peptides. Am. J. Physiol. 277, L811-L815.

Lazarowski, E. R. and Boucher, R. C. (2009) Purinergic receptors in airway epithelia. Curr. Opin. Pharmacol. 9, 262-267.

Lee, C. J., Paik, S. H., Ko, K. H. and Kim, K. C. (2002) Effects of polycationic peptides on mucin release from airway goblet cells: relationship between polymer size and activity. Inflamm. Res. 51, 490-494.

Li, J. D., Dohrman, A. F., Gallup, M., Miyata, S., Gum, J. R., Kim, Y. S., Nadel, J. A., Prince, A. and Basbaum, C. B. (1997) Transcriptional activation of mucin by Pseudomonas aeruginosa lipopolysaccharide in the pathogenesis of cystic fibrosis lung disease. Proc. Natl. Acad. Sci. USA. 94, 967-972.

Miyata, T., Kai, H., Saito, M., Okano, Y., Takahama, K., Nakagawa, M. and Kojima, S. (1986) Effects of ambroxol on pulmonary surfactant-analysis of the fatty acid composition of phosphatidylcholine in the sputum and normal respiratory tract fluid in rabbits. Nippon Yakurigaku Zasshi 88, 57-64.

Mutschler, E. and Derendorf, H. (1995) Drug actions, pp. 410-411, CRC Press, Boca Raton, Florida.

Park, S. J., Kang, S. Y., Kim, N. S. and Kim, H. M. (2002) Phosphatidylinositol 3-kinase regulates PMA-induced differentiation and superoxide production in HL-60cells. Immunopharmacol. Immunotoxicol. 24, 211-226.

Rogers, D. F. and Barnes, P. J. (2006) Treatment of airway mucus hypersecretion. Ann. Med. 38, 116-125.

Shao, M. X., Ueki, I. F. and Nadel, J. A. (2003) TNF-alpha converting enzyme mediated MUC5AC mucin expression in cultured human airway epithelial cells. Proc. Natl. Acad. Sci. USA. 100, 1161811623.

Stetinova, V., Herout, V. and Kvetina, J. (2004) In vitro and in vivo antioxidant activity of ambroxol. Clin. Exp. Med. 4, 152-158.

Takeyama, K., Dabbagh, K., Shim, J. J., Dao-Pick, T., Ueki, I. F. and Nadel, J. A. (2000) Oxidative stress causes mucin synthesis via transactivation of epidermal growth factor receptor: role of neutrophils. J. Immunol. 164, 1546-1552.

Takeyama, K., Dabbagh, K., Lee, H., Agusti, C., Lausier, J. A., Ueki, I. F., Grattan, K. M. and Nadel, J. A. (1999) Epidermal growth factor system regulates mucin production in airways. Proc. Natl. Acad. Sci. USA. 96, 3081-3086.

Voynow, J. A. and Rubin, B. K. (2009) Mucins, mucus, and sputum. Chest 135, 505-512.

Wasano, K., Kim, K. C., Niles, R. M. and Brody, J.S. (1988) Membrane differentiation markers of airway epithelial secretory cells. J. Histochem. Cytochem. 36, 167-178.

Yuan-Chen Wu, D., Wu, R., Reddy, S. P., Lee, Y. C. and Chang, M. M. (2007) Distinctive epidermal growth factor receptor/extracellular regulated kinase-independent and -dependent signaling pathways in the induction of airway mucin $5 \mathrm{~B}$ and mucin $5 \mathrm{AC}$ expression by phorbol 12-myristate 13-acetate. Am. J. Pathol. 170, 20-32. 